\title{
Impact of Business Incubators on Economic Growth and Entrepreneurship Development
}

\author{
Ogutu $^{1}$, V. O. ${ }^{1}$, Kihonge E. ${ }^{2}$ \\ ${ }^{1}$ Jomo Kenyatta University of Agriculture and Technology, Department of Human Resource Development, P.O Box 62000-00200, Nairobi, \\ Kenya \\ ${ }^{2}$ Jomo Kenyatta University of Agriculture and Technology, Department of Human Resource Development, P.O Box 62000-00200, Nairobi, \\ Kenya
}

\begin{abstract}
There has been great interest globally to increase the survival rate of SME's, owing to their innate potential of spurring economic growth, creating employment and poverty reduction. The motivation of this paper was to find out if there is a relationship between the number of incubators in a country and the Gross Domestic product. The study surveyed selected countries in Asia, America's, Africa and Europe. The study used historical data published and through content analysis and statistical analysis was able to establish a strong relationship between the numbers of incubators a country has influences the country's GDP very strongly.
\end{abstract}

Keywords: Business Incubation, Economic growth and entrepreneurship development

\section{Introduction}

There is growing interest globally on Business Incubators and their perceived role they play in the survival of start-ups. Business incubators are seen as the "magic bullet" that would arrest the high failure rate among Small and Medium size enterprises (SME) in the developing world estimated at approximately $75 \%$ within three years (Longnecker et al, 2006; Bowen et al, 2009; Klapper et al, 2009). Experience gained with incubated businesses estimate the survival post incubation to be as high as $70 \%$. Increasing the success rate of start-ups and SME's in terms of increasing their survival can have profound effect on employment creation, economic development and poverty reduction (Aerts et al., 2007).

Business incubators are defined as a "conducive environment where start-ups, new ventures are nurtured, ideas are developed to commercialization thereby building profitable, sustainable and scalable enterprises without exposing them to the harsh realities of business environment and high start-up costs. In the incubator tenants are offered training, mentorship and business support services" The definition is based on the infrastructure and the services portfolio.

The survival of SME's are seen as an important component of economic growth and development especially among developing countries. Evidence from fast growing economies show that governments that support enterprise development by providing a suitable business environment for creation, growth and proliferation of SME's rip exceptionally high dividends in terms of increased employment opportunities especially for the youth, economic growth and poverty reduction (Ayyagari et al, 2011).

There has been reports of high failure rate of start-ups both in the developed and developing world. In Australia SME failure rate is $23 \%$, in Malaysia SME failure rate is $60 \%$ (Ahmed \& Seet, 2009). In South Africa, SME failure rate of $75 \%$ has been reported, many fail before two years (FinMark
Trust, 2006), In Kenya, Njonjo (2010) reported a failure rate of $60 \%$ in three years. According to SBA (2008) three in five new firms collapse within a few months of operation.

The motivation for this seminar paper is informed by the desire to examine if Business incubators are catalysts to entrepreneurship development by exploring their role in SME development, creation of start-ups, survival of startups and eventually their contribution to economic development by being the foundation and cornerstone of employment creation, wealth creation and poverty reduction.

The study is organized in the following format: overview of business incubation globally, examining representative countries from a sample of twelve, regionally covering Europe, America's, Asia and Africa, an in-depth case study of Germany and through comparative analysis with keen interest to their contribution to entrepreneurship development measured in terms of Gross Domestic product (GDP) growth and Total Entrepreneurship Activity (TEA), statistical analysis of historical data and lastly conclusion and recommendations.

\subsection{Overview of Business Incubation}

The History of Business Incubation is a rich one. It is believed that the first incubator originated in New York as Batavia Industrial Centre (BIC) back in 1959. (Meru et al.,2011 \& Lewis, 2002). Extensive growth of Business Incubators happened in the 1980's and 1990's. There are approximately $5000-7000$ Business Incubators globally majority existing in USA and China. Summary of Business incubators distribution in Table 1.0.

The National Business Incubator Associations (NBIA) defines Business incubators as "Business support process that accelerates the successful development of start-ups and fledging companies by providing entrepreneurs with an array of targeted resources and services" 


\section{International Journal of Science and Research (IJSR) \\ ISSN (Online): 2319-7064 \\ Index Copernicus Value (2013): 6.14 | Impact Factor (2015): 6.391}

Is there a connection between the number of start-ups, GDP of a country, number of Incubators and the policy support? If there exists a connection is it then right to assume that this connection has a profound effect on economic growth?

There are different types of incubators namely: University based/linked incubators, Government (Public) run/supported incubators, private incubators and corporate incubators. Business incubators are also classified by specialization sector e.g. Technology Incubator or mixed incubator catering for mixed tenants in different business sectors/industry. In addition the business incubators differ in their structures, policies, tenants, management, funding and their outcomes in terms of; are they achieving the desired results they were created and best practice in incubation (Lalkaka, 2002; Amezcua, 2011, Al-Mubaraki et al, 2012).

Business incubators have evolved from offering workspaces, shared facilities like telephone, internet, secretarial services, meeting rooms and basic furniture to include business support services like training, business plan writing, legal and accounting support services, intellectual property protection, market access support, networking within and without the incubator and lastly linking tenants to sources of finance namely venture capital firms, angel investors, banks and other finance institutions supportive of SME's (Lalkaka, 1997; Meru et al; Amezcua et al, 2014; Masutha et al, 2014; Hackett et al, 2004; Hannon et al, 2004 \& Al Mubaraki et al, 2012)

Countries like Brazil, Israel, South Korea and Spain have made considerable economic development over the years. Taking a keen look at factors that have enabled the rapid economic growth it is clear an enabling operating environment, entrepreneurship support policies, government support to technology diffusion, market access as well as business support services including Business incubation, investment in Research and development and heavy investment in Human Capital (training and development in tertiary institutions and Universities) according to Perry (2009).

Table 1: Countries and Number of Business Incubators

\begin{tabular}{|c|c|c|c|c|}
\hline No & Country & No. of Incubators & Year & Source: Author/Study \\
\hline 1 & USA & 1115 & 2007 & Knopp, 2007 \\
\hline 2 & China & 1000 & 2009 & Lalkaka (1997); Lilai, X. (2009) \\
\hline 3 & Germany & 375 & 2013 & SPICA directory (2010), Paragivtis Liargovas (2013) \\
\hline 4 & Spain & 38 & 2013 & SPICA directory $(2010)$ \\
\hline 5 & Israel & 24 & 2012 & $\begin{array}{c}\text { Ministry of industry, trade and Labour office of chief Scientist (2012), Paragivtis } \\
\text { Liargovas (2013) }\end{array}$ \\
\hline 6 & South Korea & 300 & 2008 & Richards (2002) cited in Ndabeni (2008), Cho \& Eunsuk (2009) \\
\hline 7 & Brazil & 400 & 2012 & $\begin{array}{c}\text { ANPROTEC (2012) Brazilian association of Business incubators and } \\
\text { Technology parks }\end{array}$ \\
\hline 8 & Mexico & 191 & 2003 & Lalkaka $(1997,2003)$ \\
\hline 9 & Nigeria & 25 & 2009 & Adelowo et al, 2009, Adegbite et al, 2001 \\
\hline 10 & Ghana & 3 & 2016 & Addo, R (2016), Incubator manager (NBIA) Ghana. \\
\hline 11 & South Africa & 51 & 2014 & Masutha, 2014 \\
\hline 12 & Kenya & 12 & 2011 & BIAK, Meruet al, (2011) \\
\hline
\end{tabular}

Source: Author

Business incubation services can be divided into three preincubation, incubation and post incubation this incorporates different processes and procedures that govern the incubator-incubate (Tenant) relationship. Pre-incubation includes the process of attracting, application, vetting of potential tenants of the incubator. The terms and conditions including agreement on rent payment, duration in the incubator and use of the facilities. Incubation includes support from idea crystallization and development, prototype building to commercialization.

The key performance indicators on progress reports, gaps identification and filling with the help of incubator management, networking, financing, marketing and business acceleration. Post incubation this is the period after graduation from the incubator where the tenant business has exited the incubator and follow up on progress by the incubator staff to monitor progress and maintain relations with previous tenant firms. This is usually done virtually, through physical visits and through incubator seminars and workshops invitations.

Best practice in business incubation: Winston Churchill said, "Incubation is the worst form of Business development service, with the exception of all the alternatives" For an incubator to succeed it needs certain salient characteristics namely: clear metrics for success, provide entrepreneurship leadership, develop and deliver value to tenants, have a rational tenant selection system and lastly assist tenant firms access finance, human, networking and mentorship resources. (Lalkaka, 1997; Wiggens \& Gibson, 2003; Malefane, 2013).

\subsection{Related Studies in Business Incubation}

Incubation is a strategic tool of enterprise development and economic growth, it provides a "leap from imitation to innovation" (Lalkaka, 1997). It provides business support to high potential high growth enterprises. Where the incubator is based has shown positive impact in the community by encouraging innovation and entrepreneurship development in the community. Most of the incubated businesses stay within the community. This shows that incubators have the capacity to stir development in the surrounding neighborhood based on experience with Silicon Valley in the USA and Tel Aviv in Israel are surrounded by universities, Science and innovation parks. 


\section{International Journal of Science and Research (IJSR) \\ ISSN (Online): 2319-7064 \\ Index Copernicus Value (2013): 6.14 | Impact Factor (2015): 6.391}

When Stanford University in the USA had challenges getting firms where engineering graduates could have hands on experience, the university encouraged partnerships with graduating students to start businesses out of innovative ideas to provide a vehicle for engineering graduates internship opportunities in San Francisco.

Business Incubation is a model of building entrepreneurial capacity; it provides start-ups with networks for building relationships. Incubators offer training, business support, technology support, infrastructure and mentoring. These elements are crucial in survival of start-ups without much capital to develop into a full fledge enterprise. Incubators provide work space, furniture, legal, back office services that incubates need not worry about. A study by Meru et al. (2011) to establish entrepreneurs' perception on businessincubators importance in Kenya, reported a significant relationship although there was a disconnect between the actual services delivered and the expectations of the tenants. The services delivered fell short tenants expectations.

In a study in Spain on the influence of training and gender in entrepreneurship through business incubators in Galicia, established a positive relationship on incubators assisting incubates to start business, noting that majority of the citizens prefer civil service jobs to entrepreneurship (Seoane, 2014).

Studies in Brazil reveal that Incubators in Brazil have been relatively successful due to bench marking for excellence with focus to specific industries, strong monitoring and Evaluation of tenants' progress and lastly move towards financial viability and sustainability after 3 years post establishment. The infrastructure is further linked to access to finance, export orientation and employment creation (Lalkaka, 1997; Jorge \& Rivera, 2007)

There have been studies on Incubation in South Africa. Incubation started in South Africa in the 1990's with "hives of Industry" model. Experience in South Africa shows that incubation needs Management, Market and money to succeed. Where management mean having business incubator managers with strong business management skills in book keeping, business plan development, marketing skills, networking linkages able to link tenant firms with markets, venture capital as well as business development trainings ( Masutha, 2014).

Table 1.1: Selected Countries GDP in Billion

\begin{tabular}{|l|l|l|l|l|l|l|l|}
\hline No & Country & $\mathbf{1 9 8 0}$ & $\mathbf{1 9 9 0}$ & $\mathbf{2 0 0 0}$ & $\mathbf{2 0 1 1}$ & $\mathbf{2 0 1 3}$ & $\mathbf{2 0 1 5}$ \\
\hline 1 & USA & 2862 & 5980 & 10285 & 15518 & 16663 & 17968 \\
\hline 2 & China & 304 & 393 & 1205 & 7493 & 9491 & 11385 \\
\hline 3 & Germany & 851 & 1593 & 1956 & 3761 & 3746 & 3371 \\
\hline 4 & Spain & 230 & 534 & 579 & 1496 & 1393 & 1221 \\
\hline 5 & Israel & & 58 & 132 & 262 & 292 & 291 \\
\hline 6 & South Korea & 65 & 279 & 562 & 1202 & 1306 & 1393 \\
\hline 7 & Brazil & 152 & 475 & 657 & 2613 & 2391 & 1800 \\
\hline 8 & Mexico & 235 & 298 & 684 & 1171 & 1262 & 1161 \\
\hline 9 & Nigeria & 62 & 36 & 61 & 419 & 522 & 493 \\
\hline 10 & Ghana & 26 & 8.8 & 7.4 & 39.6 & 47.8 & 37.7 \\
\hline 11 & South Africa & 83 & 116 & 136 & 417 & 366 & 317 \\
\hline 12 & Kenya & 10.1 & 12.2 & 14.1 & 42 & 54.9 & 63.1 \\
\hline
\end{tabular}

Source: World Bank (2016)
Germany has the most sophisticated business incubation in the world. This explains why Germany is the largest economy in Europe (Table 1.1 \& Table 1.2). It is supported by an integrated business support ecosystem that involves universities, national and local government, sources of funding and existence of technology and start-up centres devolved all over Germany. Taking Germany as a representative Model of incubation and examining the composition of start-ups entrepreneurs summarized in Table 1.4 .

Gross Domestic Product (GDP) is a measure /reflection of the size of the economy in dollar terms. The Table 1.1 shows that USA is the leading economy followed by China. When looking at the per Capita income which is a measure of a countries wealth per person in dollar terms this shows that USA followed by Germany are real strong economies with citizens relatively wealthy.

Table 1.2: Selected Countries GDP per Capita Income in $\$$

\begin{tabular}{|l|l|l|l|l|}
\hline No & Country & $\mathbf{2 0 1 3}$ & $\mathbf{2 0 1 4}$ & $\mathbf{2 0 1 5}$ \\
\hline 1 & USA & 52608 & 54370 & 55904 \\
\hline 2 & China & 6975 & 7572 & 8280 \\
\hline 3 & Germany & 46386 & 47774 & 41267 \\
\hline 4 & Spain & 29907 & 30272 & 26327 \\
\hline 5 & Israel & 36297 & 37222 & 35702 \\
\hline 6 & South Korea & 25998 & 27970 & 27513 \\
\hline 7 & Brazil & 11894 & 11573 & 8802 \\
\hline 8 & Mexico & 10658 & 10784 & 9592 \\
\hline 9 & Nigeria & 3082 & 3300 & 2758 \\
\hline 10 & Ghana & 1870 & 1473 & 1401 \\
\hline 11 & South Africa & 6890 & 6483 & 5784 \\
\hline 12 & Kenya & 1314 & 1420 & 1432 \\
\hline
\end{tabular}

Source: World Bank (2016)

The level of Total early entrepreneurship activity (TEA) in a country differs according to the different phases of economic development according to Porter namely factors driven, efficiency driven and innovation driven phases of economic development. Countries in the early economic development (Majorly relying on factors of production) tend to have very high TEA and exhibit lower GDP compared to countries in the efficiency phase and the innovation phase of economic development.

Table 1.3 show the global ranking of TEA in terms of highly innovative economies in 2012. This is a measure of the new Total new start-up entrepreneurial activity which is a measure of the percentage of new enterprises (start-ups less than 42 months old) relative the population normally reported in the Global entrepreneurship monitor (Sternberg et al, 2013). 


\section{International Journal of Science and Research (IJSR) \\ ISSN (Online): 2319-7064 \\ Index Copernicus Value (2013): 6.14 | Impact Factor (2015): 6.391}

Table 1.3: Selected Countries Total Early Stage Entrepreneurial Activity (TEA)

\begin{tabular}{|l|l|l|l|l|l|l|}
\hline No & Country & $\begin{array}{l}\text { Drivers of } \\
\text { economic } \\
\text { development }\end{array}$ & $\begin{array}{l}\text { Rank } \\
2012\end{array}$ & $\begin{array}{l}\text { TEA } \\
\% \\
2013\end{array}$ & $\begin{array}{l}\text { TEA } \\
\% \\
2014\end{array}$ & $\begin{array}{l}\text { TEA } \\
\% \\
2015\end{array}$ \\
\hline 1 & USA & Innovation & 1 & 12.7 & 13.8 & 14 \\
\hline 2 & China & Efficiency & & 14 & 15.5 & 13.5 \\
\hline 3 & Germany & Innovation & 20 & 5 & 5.3 & 5 \\
\hline 4 & Spain & Innovation & 17 & 5.2 & 5.5 & 5.47 \\
\hline 5 & Israel & Efficiency & 11 & 10 & & 13 \\
\hline 6 & $\begin{array}{l}\text { South } \\
\text { Korea }\end{array}$ & Efficiency & 10 & 6.9 & & 13 \\
\hline 7 & Brazil & Efficiency & & 17.3 & 17.2 & 17 \\
\hline 8 & Mexico & Efficiency & & 14.8 & 19 & 18 \\
\hline 9 & Taiwan & Innovation & 8 & 8.2 & 8.5 & 8 \\
\hline 10 & Ghana & Factors & & 25.8 & & \\
\hline 11 & $\begin{array}{l}\text { South } \\
\text { Africa }\end{array}$ & Efficiency & \multicolumn{1}{|l|}{10.6} & 7 & 8 \\
\hline 12 & Kenya & Factors & & & & \\
\hline Source Sternberg al & & & & \\
\hline
\end{tabular}

Source: Sternberg et al. (2013), GEM (2014) \& Author

Table 1.4 shows the new entrepreneur's types in the Germany economy

This Study picks Germany as a representative case of best practice in Business Incubation and attempts to compare
Germany with the other selected 11 countries. Germany's case is evaluated in details as a bench mark to other countries.

Table 1.4: New entrepreneur's types in the Germany economy

\begin{tabular}{|l|l|l|l|}
\hline Type of new entrepreneurship & $\mathbf{2 0 1 0}$ & $\mathbf{2 0 1 1}$ & $\mathbf{2 0 1 2}$ \\
\hline All new entrepreneurs & 941,000 & 835,000 & 775,000 \\
\hline Full time entrepreneurs & 401,000 & 381,000 & 315,000 \\
\hline Side entrepreneurs & 540,000 & 454,000 & 460,000 \\
\hline Opportunity entrepreneurs & 356,000 & 292,000 & 361,000 \\
\hline Entrepreneurship freelancers & 270,000 & 300,000 & 303,000 \\
\hline
\end{tabular}

Kfw (2013c)

From the data provided above in terms of the size of the economy in terms of GDP (Table 1.1), per capita income (Table 1.2), the number of incubators in selected countries (Table 1.0) and the level of Total Early stage Entrepreneurship Activity (TEA), Table 1.3 and lastly the composition of new entrepreneurs in Germany (Table 1.4).There is a strong case on the role of incubation in the overall promotion of entrepreneurship development and economic development by creation, development of enterprises and creation of jobs(Waeltring\& Dornberger, 2014).

Table 1.5: Data Summary

\begin{tabular}{|l|c|c|c|c|c|}
\hline COUNTRY & $\begin{array}{c}\text { No. of } \\
\text { Incubators }\end{array}$ & $\begin{array}{c}\text { GDP in B } \\
\$\end{array}$ & Per Capita in \$ & $\begin{array}{c}\text { Total Entrepreneurship } \\
\text { Activity (TEA) } \%\end{array}$ & $\begin{array}{c}\text { Economic Drivers - } \\
\text { Porter's }\end{array}$ \\
\hline USA & 1115 & 16663 & 52608 & 12.7 & INNOVATION \\
\hline CHINA & 1000 & 9491 & 6975 & 14 & EFFICINCY \\
\hline BRAZIL & 400 & 2391 & 11894 & 17.3 & EFFICIENCY \\
\hline GERMANY & 375 & 3746 & 46386 & 5 & INNOVATION \\
\hline SOUTH KOREA & 300 & 1306 & 25998 & 14.8 & INNOVATION \\
\hline MEXICO & 191 & 1262 & 10658 & 6.8 & EFFICIENCY \\
\hline SOUTH AFRICA & 51 & 366 & 6890 & 5.2 & EFFICIENCY \\
\hline SPAIN & 38 & 1393 & 29907 & 8.2 & FACTOR \\
\hline NIGERIA & 25 & 522 & 3082 & 10 & EFFICIENCY \\
\hline ISRAEL & 24 & 292 & 36297 & 26 & FACTOR \\
\hline KENYA & 12 & 54.9 & 1314 & 25.8 & FACTOR \\
\hline GHANA & 3 & 47.8 & 1870 & & \\
\hline
\end{tabular}

The table 1.5 summarizes the study data in terms of the number of incubators from secondary sources, GDP from world bank global reports, per capita in $\$$ from world bank reports, Total entrepreneurship activity from Global Entrepreneurship Monitor (GEM) and porters classification of countries based on economic drivers.

\subsection{Entrepreneurship development}

Entrepreneurship development is a process of endearing entrepreneurship culture by promoting entrepreneurship mind set, enhancing creativity and innovation, entrepreneurship education, encouraging entrepreneurship orientation and supporting creation and growth of new ventures. The debate on whether entrepreneurs are born or they are made is still unresolved. With the right operating environment and pro- entrepreneurship ecosystem in terms of easy of policy compliance, availability of funding, good infrastructure, access to information, markets, availability of suitable technology and business support services are important elements that encourage entrepreneurship.
Entrepreneurship development in essence is the promotion of entrepreneurship mindset, entrepreneurship orientation, entrepreneurship motivation and entrepreneurship growth support as a possible outcome of incubation. This is perceived to have a positive impact on economic growth.

Experience in Israel has demonstrated that creating SME's with the right support ecosystem linking the academia, industry, venture capital, technology, use of incubation and business support has catapulted Israel economically in the world GDP global ranking and enhanced per capita ranking (OECD,2010; Berry, 2009). This is corroborated with experience in Germany discussed earlier in this paper.

\subsection{Incubators in Kenya}

The Business Incubators Association of Kenya notes there are 12 business incubators in Kenya. There are University linked business incubators, Private incubators, corporate linked incubators and government owned or supported 


\section{International Journal of Science and Research (IJSR) \\ ISSN (Online): 2319-7064 \\ Index Copernicus Value (2013): 6.14 | Impact Factor (2015): 6.391}

incubators. The Business incubators are generically mirror image of the incubation processes available in the world where recruitment to tenant firm is done, pre incubation based on some criteria predetermined by the incubator based on stakeholders interests. During the incubation, there are training, seminars, shared facilities, mentorship, coaching, linkages to venture capitalist, and sources of finance as well as networks within and without the incubator (Meruet al, 2011).

\subsection{Emergent issues}

Attracting potential tenants is an area of real challenge. Youths with business ideas, new innovations have no idea business incubators exist and how they can engage. Owners of innovative business ideas are sometimes also reluctant to share for fear of losing their intellectual property.

Sustainability of incubators is a key area of difficulty especially business incubators supported by the government. Many incubators are not financially self-sustaining, this limits the level of tenant service delivery. Some tenants are also unwilling to graduate from the incubators due to low rents and comfort of the incubator networks.

Incubator managers' skill sets and the needs of the tenant firms in some instances are incongruent. Business incubators need managers that are skilled in business processes, entrepreneurship development, mentorship and coaching and more so ability to assist tenant firms access finance, markets and be able to network outside the business incubator.

\subsection{Way forward}

Building a one stop ecosystem linking universitiesknowledge banks, business parks, budding entrepreneurs, venture capitalists, linkage to mentors and business coaches, targeted reach to communities, working with all stakeholders the government to have a major impact on employment creation, building high growth businesses and incorporating export/globalization strategy. Incorporating business plan competitions to tap ideas that can be incubated into global enterprises.

The modern business incubator need to market their services targeting the specific tenant types with clear process of admission, the process of incubation, have clear measurement metrics to gauge progress and success this is also called having milestones that have to be overcome before graduating. Have a post-graduation programme of monitoring progress in the real operating environment to increase survival success even further.

Is there a connection between the number of start-ups, number of Incubators and GDP of a country? Taking the best practice and factors of success in a representative country is it then possible to encourage Business Incubation as a policy instrument for entrepreneurship development and economic growth? If there exists a connection is it then right to assume that this connection has a profound effect on economic growth? This study set out to establish if this connection exists?

\section{Methodology}

This study is a prescriptive inquiry. It adopted a mixed study design including desktop, case studies using historical data. A case study is recognized as the most effective research strategy able to capture and extract in depth data from experience of complex situations. (Eisenhardt, 1989; Yin, 1994). The study is prescriptive in nature. It examined regional population distribution of incubators globally represented by Europe, Asia, Africa and the America's versus the selected countries GDP. The data was analyzed to explain the role of business incubators in entrepreneurship development globally, picking key success factors measured in terms of GDP thereafter recommending a policy case for Kenya.

The methodology involved extensive literature review in terms of regional economic performance in relation to the number of business incubators. The Study picked Germany as a representative Case of successful business incubation, support, and entrepreneurship development thus benefitting from economic growth. Apart from Germany a regional survey of Europe, America's, Asia and Africa was studied comparing GDP, number of incubators, Total entrepreneurship Activity and per capita income to establish any relationship. The data collected represented in tables 1.0 to 1.3 , was described and analyzed statistically to enable conclusions to be drawn.

\section{Data Analysis}

\subsection{Descriptive Statistics}

\subsubsection{Number of Business Incubators}

The study sought to know the number of business incubators in selected countries in the world. The results of the study are as shown in Figure 1.1. 


\section{International Journal of Science and Research (IJSR) \\ ISSN (Online): 2319-7064}

Index Copernicus Value (2013): 6.14 | Impact Factor (2015): 6.391

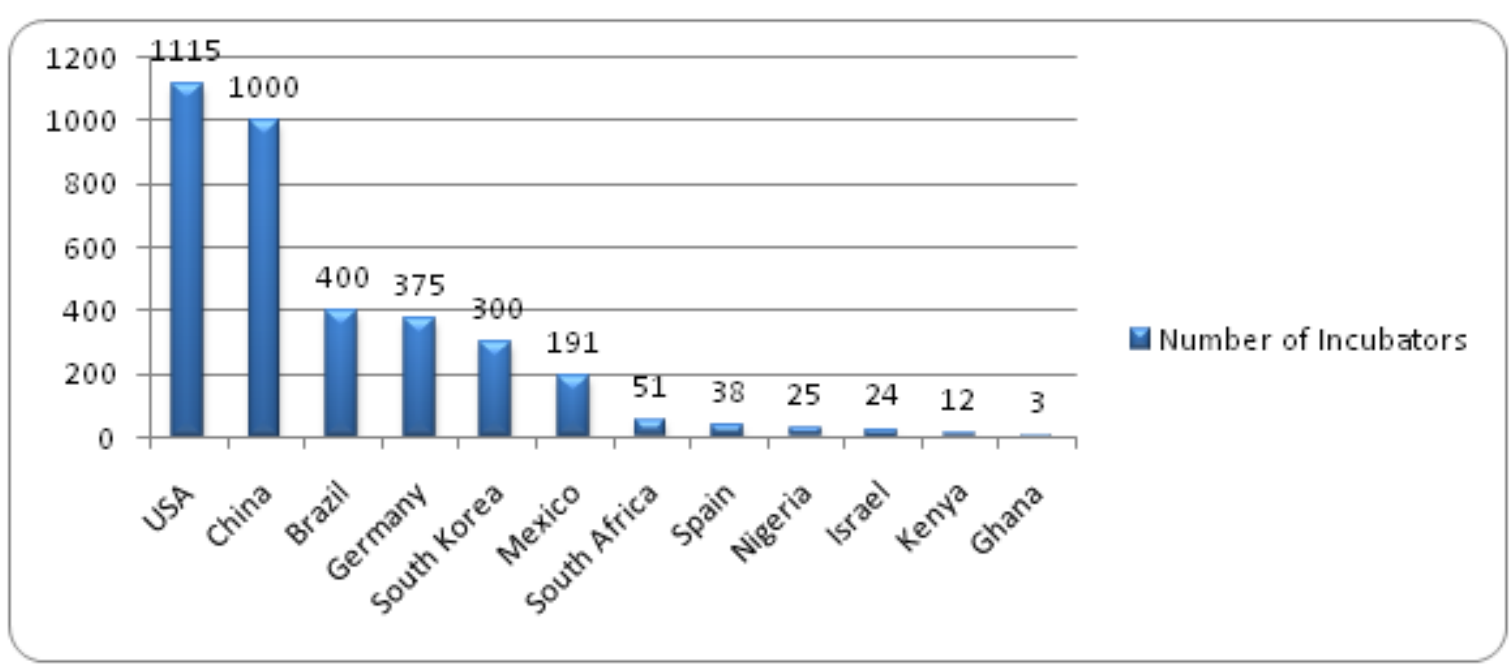

Figure 1.1: Number of Business Incubators

The study findings reveal that USA had greatest (1115) number of incubators as at 2007 followed by China with 1000 incubators in 2009 and then Brazil at 400 incubators as at 2012. Germany had 375 incubators as at 2013 while South Korea had 300 incubators as at 2008. Kenya and Ghana had the least number of incubators at 12 and 3 as at 2011 and 2016 respectively. Based on Table $\mathbf{1 . 0}$

\subsubsection{Trends in Economic Growth of Selected Countries}

The study sought to establish the Gross Domestic Product (GDP) of various selected countries in the world. Gross Domestic Product (GDP) was used as an indicator of economic growth for those countries. The trend of growth is as depicted in the figures 1.2 shown below.

The study findings reveal that USA, China and Germany recorded the highest economic growth over time compared to the other selected countries. Kenya and Ghana recorded the slowest growth in the economy. Compared to the number of incubators, the countries with high economic growth also have the highest number of incubators.

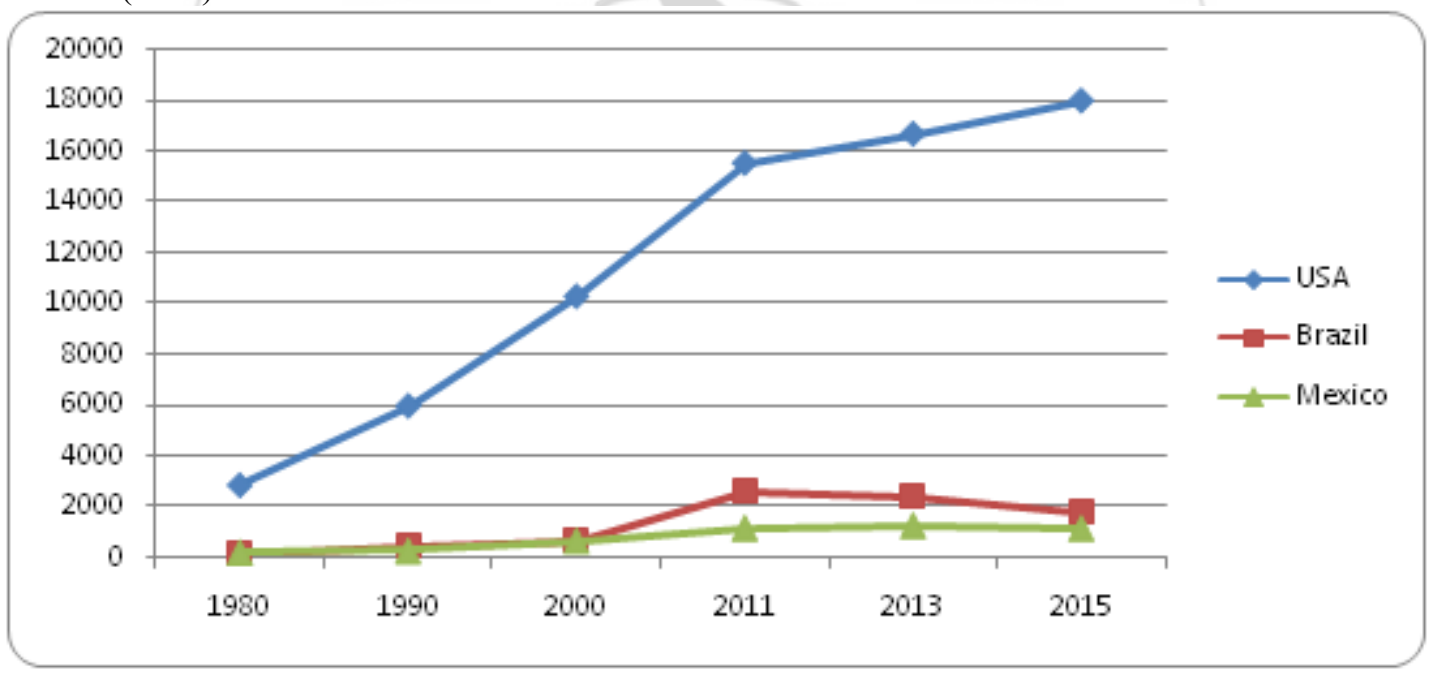

Figure 1.2: Economic Growth of Americas

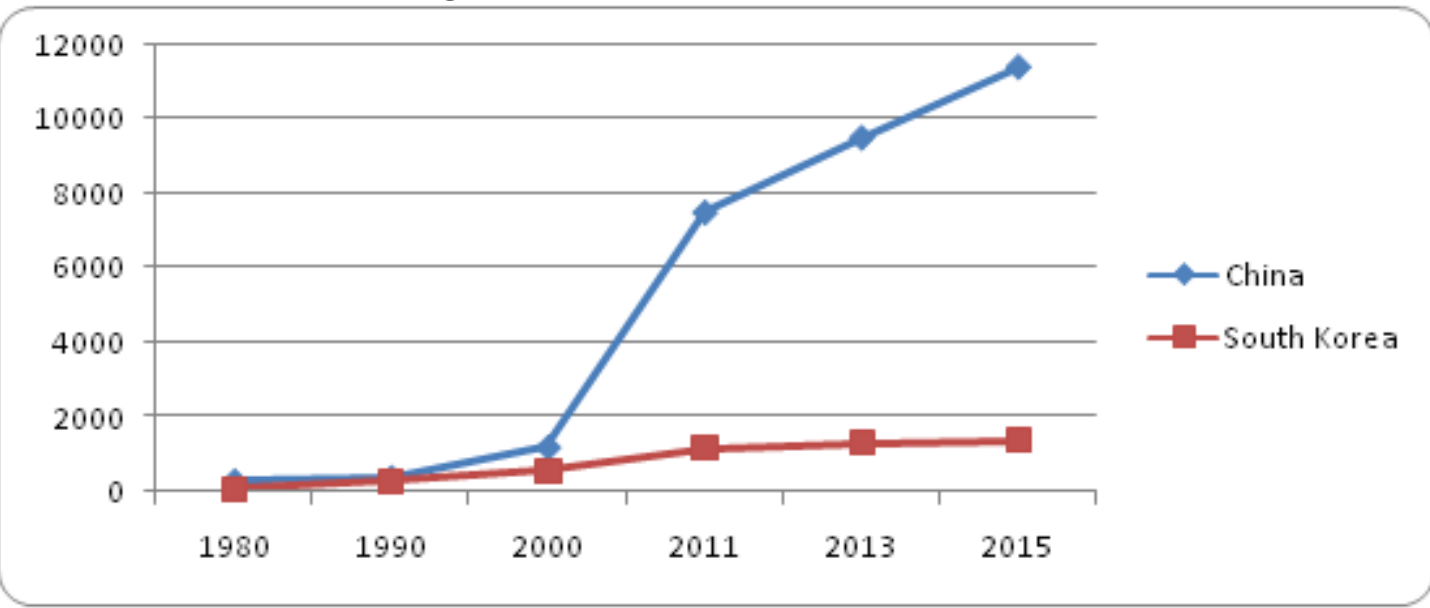

Figure 1.3: Economic Growth of Asia

Volume 5 Issue 5, May 2016 www.ijsr.net 
International Journal of Science and Research (IJSR)

ISSN (Online): 2319-7064

Index Copernicus Value (2013): 6.14 | Impact Factor (2015): 6.391

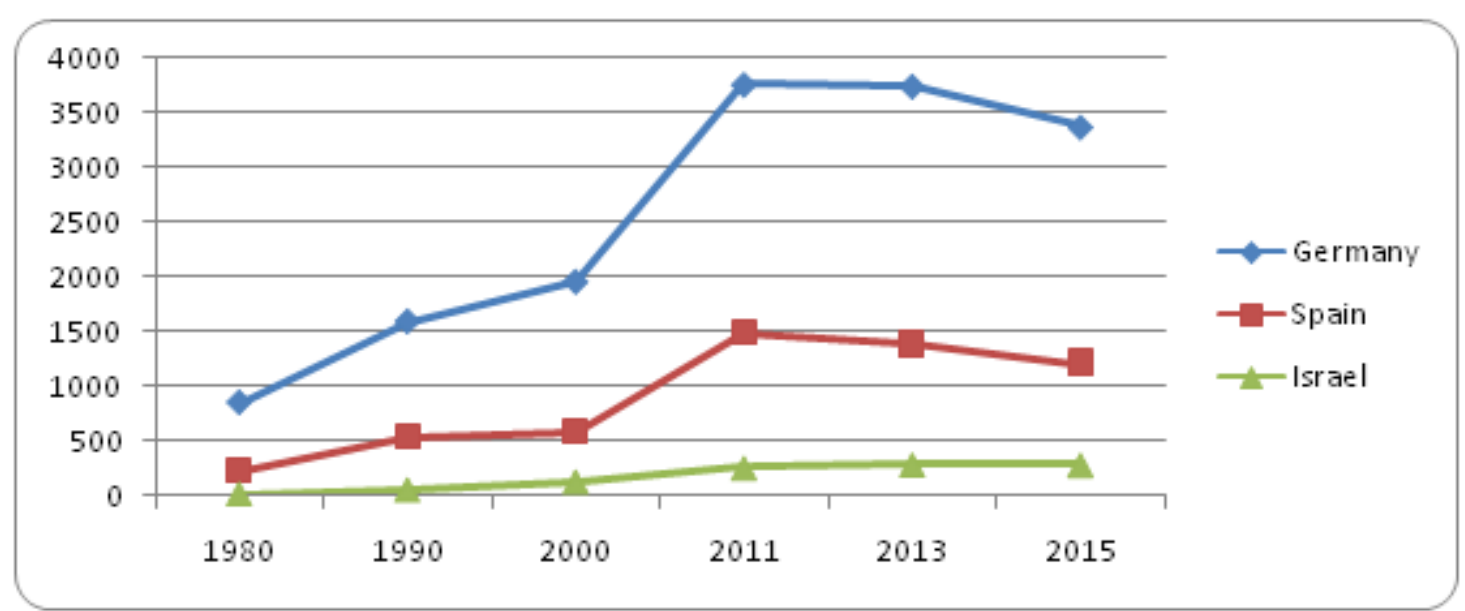

Figure 1.4: Economic Growth of Europe

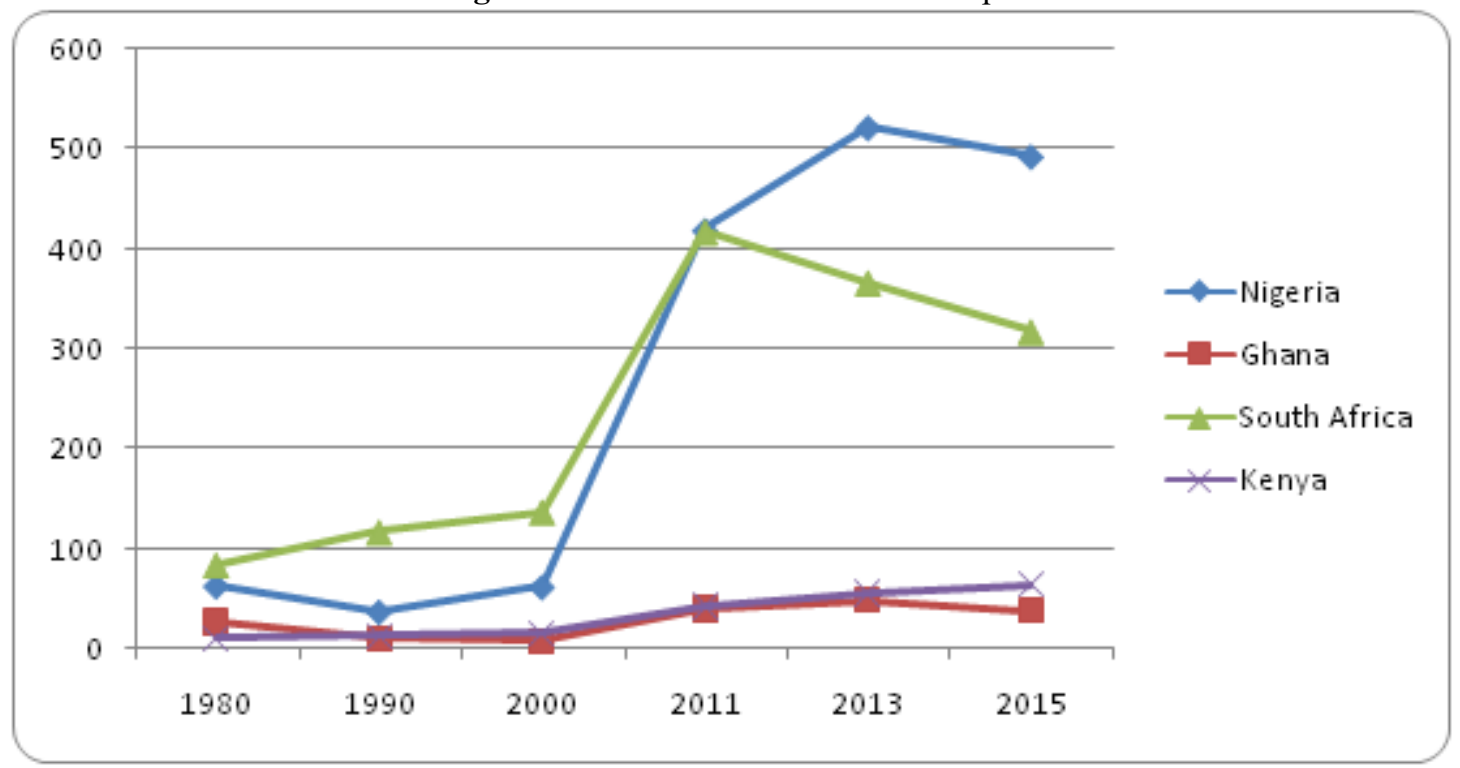

Figure 1.5: Economic Growth of Africa

\subsubsection{Trends in GDP per Capita of Selected Countries}

The study further sought to know the GDP per Capita of Selected Countries. The trend of growth in GDP per capita of selected countries is as shown in the figures $1.6-1.9$ below. In Americas, USA recorded the highest GDP per Capita while in Europe, Germany recorded the highest. In Asia, South Korea recorded higher GDP per Capita than
China. This can be attributed to the high population of China. In Africa, Kenya recorded higher GDP per Capita than economically well-endowed countries like Nigeria and South Africa. This is also attributable to the lower population of Kenya compared to Nigeria and South Africa.

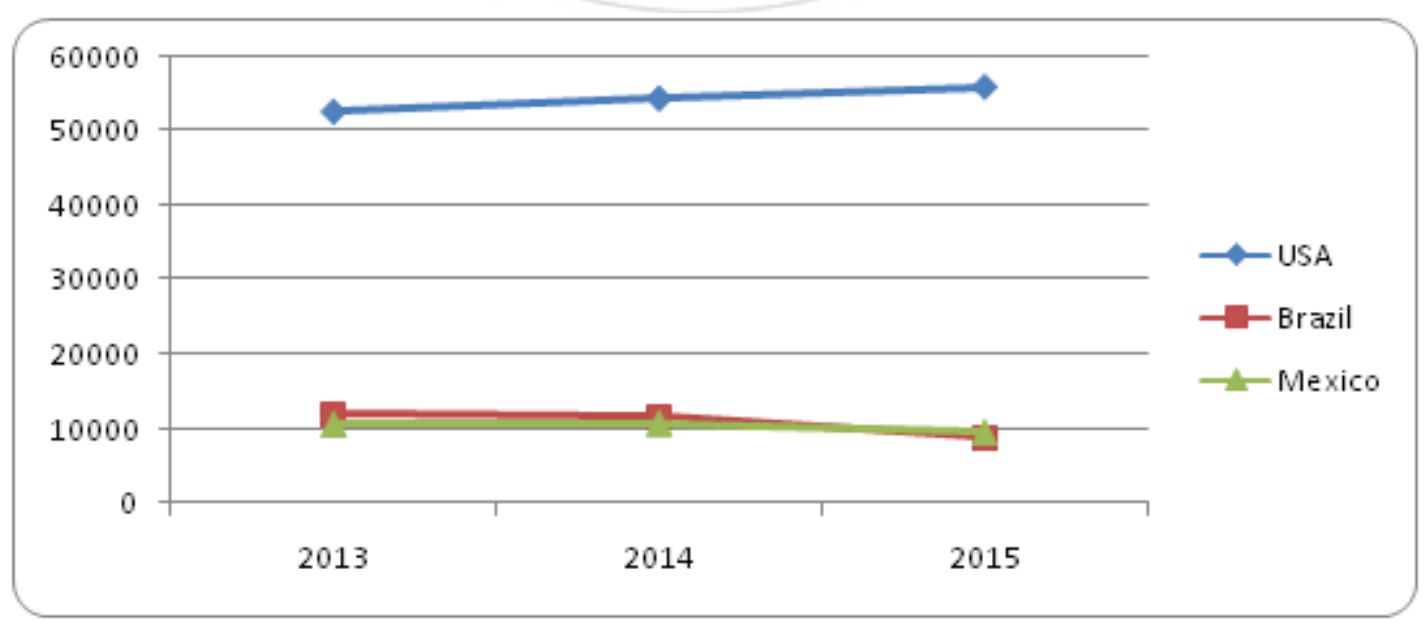

Figure 1.6: GDP per Capita of Americas 
International Journal of Science and Research (IJSR)

ISSN (Online): 2319-7064

Index Copernicus Value (2013): 6.14 | Impact Factor (2015): 6.391

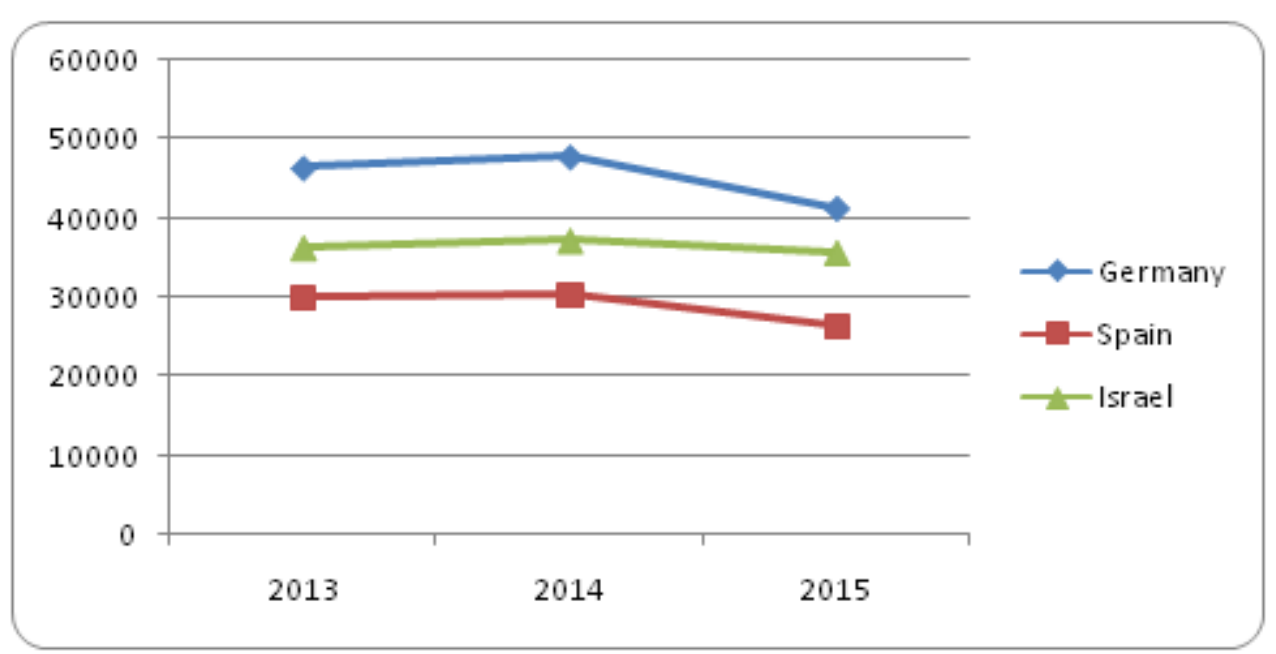

Figure 1.7: GDP per Capita of Europe

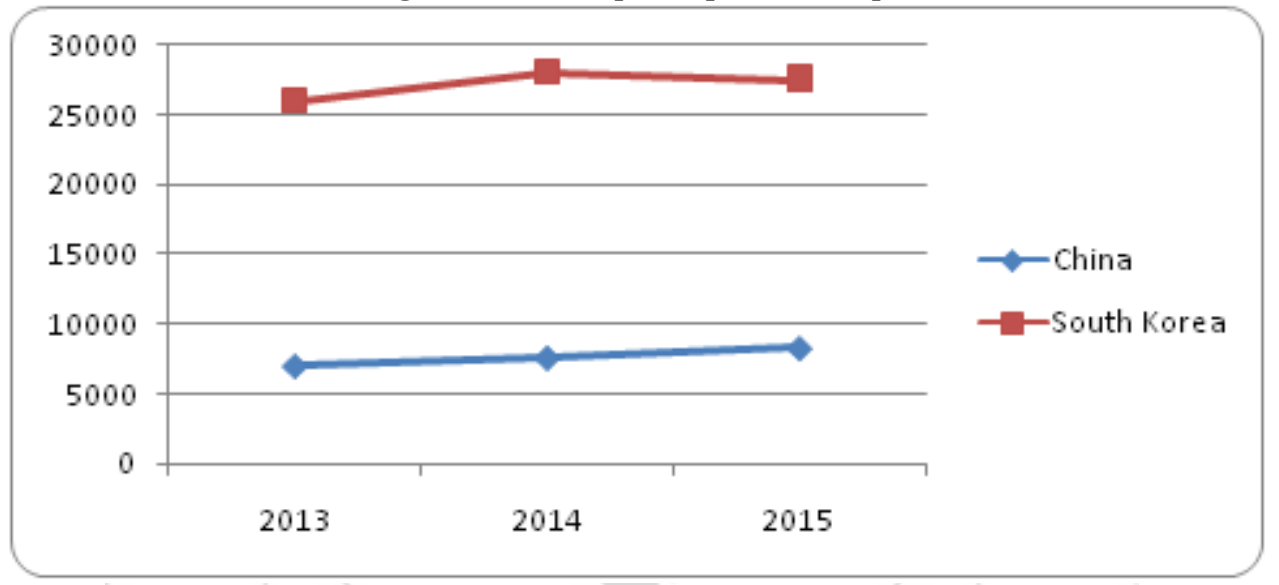

Figure 1.8: GDP per Capita of Asia

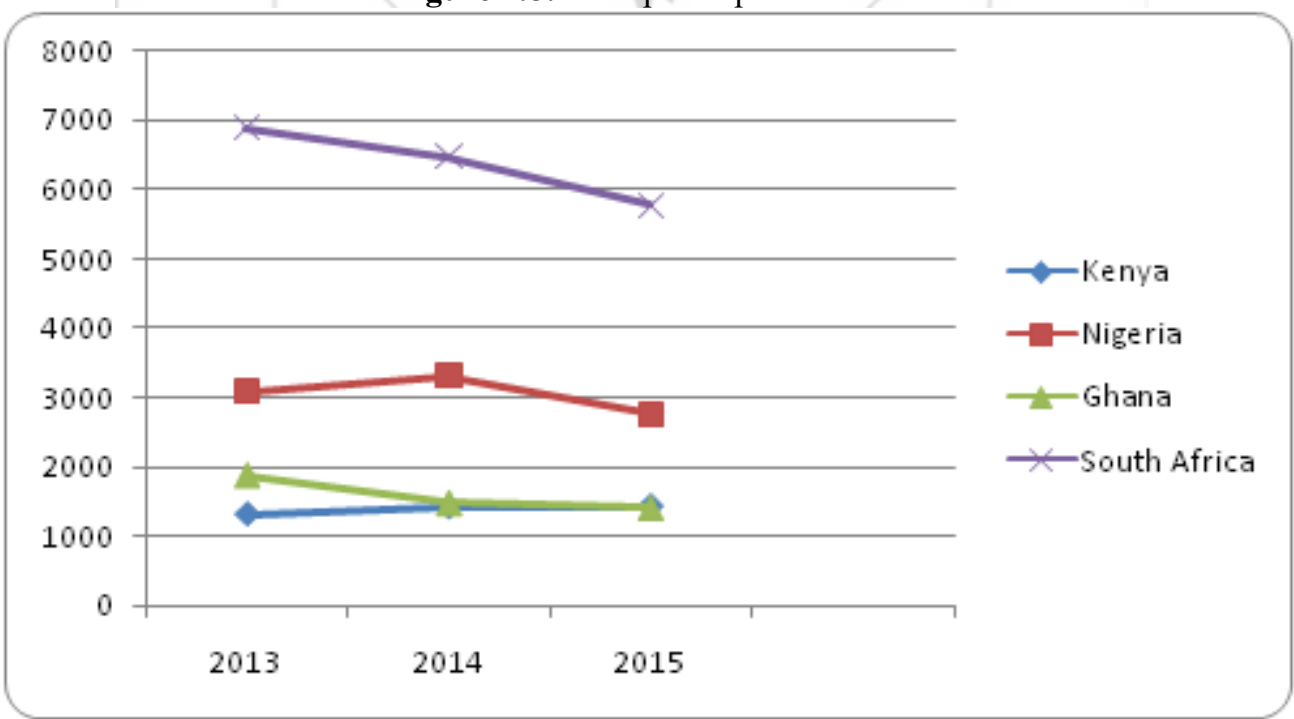

Figure 1.9: GDP per Capita of Africa

\subsubsection{Trends in TEA of Selected Countries}

In this section, the study sought to know the Total Early

Stage Entrepreneurial Activity (TEA) of selected countries.

The trends in TEA of selected countries are as shown in the figures 1.10. The results indicate that Kenya had the highest TEA of $26 \%$ followed by Ghana at $25.8 \%$ and then Brazil at $17.3 \%$. Spain and Germany had the smallest TEA at $5.2 \%$ and $5 \%$ respectively. 


\section{International Journal of Science and Research (IJSR) \\ ISSN (Online): 2319-7064}

Index Copernicus Value (2013): 6.14 | Impact Factor (2015): 6.391

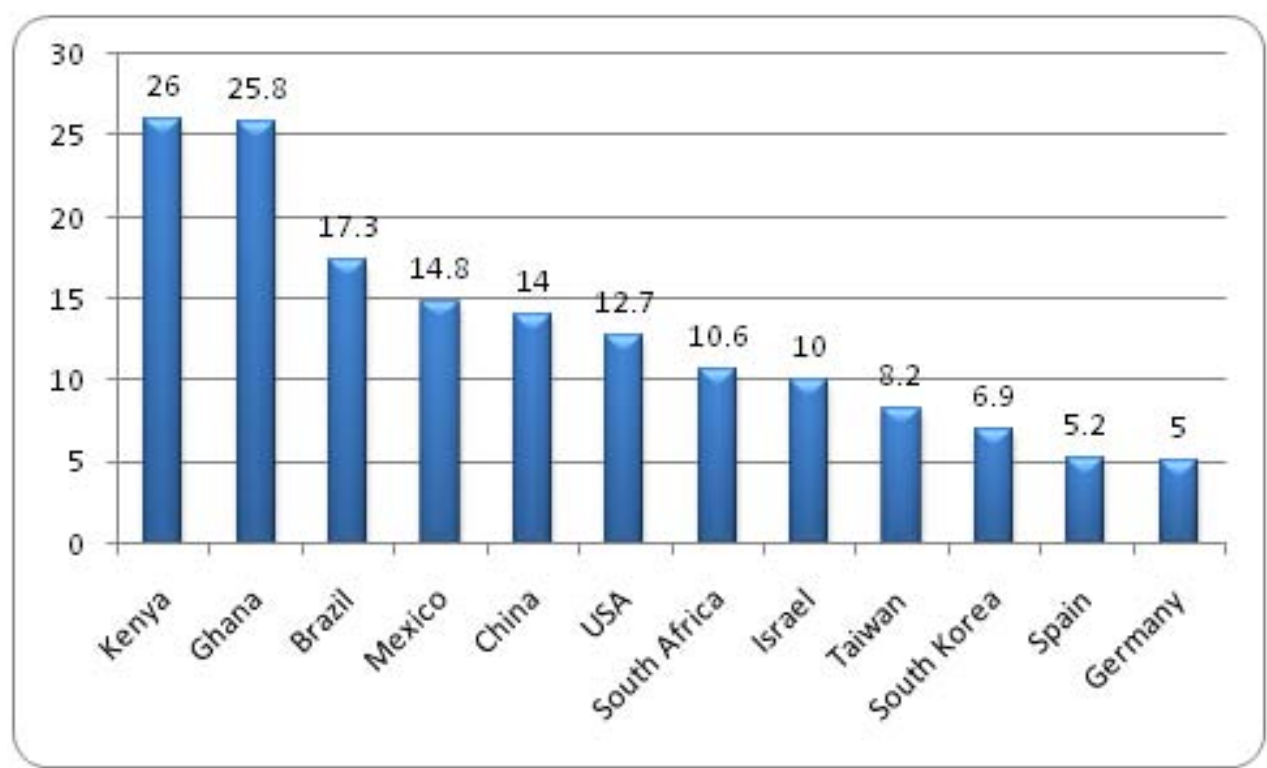

Figure 1.10: Trends in TEA of Selected Countries (2013)

\subsection{Inferential Statistics}

Regression analysis was used to establish whether there is any relationship between the number of incubators and the economic growth of a country.GDP of a countrywas used as the proxy for the financial performance and entrepreneurship development of the sampled countries. The results obtained are as discussed below.

\subsubsection{Model Summary}

Table 1.5: Model Summary

\begin{tabular}{|c|c|c|c|c|}
\hline Model & R & R Square & Adjusted R Square & $\begin{array}{c}\text { Std. Error of the } \\
\text { Estimate }\end{array}$ \\
\hline 1 & $.927^{\mathrm{a}}$ & .859 & .807 & 169.46296 \\
\hline
\end{tabular}

a. Predictors: (Constant), Total Early-entrepreneurship Activity (TEA), Gross Domestic Product (GDP), Per Capita GDP

Source: Research Findings (2016)
The study sought to establish the relationship between the number of incubators and the economic growth of a country.Gross Domestic Product (GDP), Total Earlyentrepreneurship Activity (TEA) and Per Capita GDPwere used as the independent variables. The research findings indicated that there was a very strong relationship $(\mathrm{R}=$ 0.927 ) between the number of incubators and the economic growth of a country. The result of the study also indicated that the value of adjusted R-squared is 0.807 . This implies that changes in economic growth of a country accounts for $80.7 \%$ of the total variance in the number of incubators in a country.

\subsubsection{Regression Coefficients}

Standardized coefficients of determination are used to substitute the unknown beta values of the regression model. The beta values indicate the direction of the relationship. The significant values (P-value) under sig. column indicate the strength of the relationship. A p-value of less than 0.05 is recommended as it signifies a high degree of confidence. A value above 0.05 indicates a statistically insignificant relationship.

Table 1.6: Regression Coefficients

\begin{tabular}{|c|c|c|c|c|c|}
\hline \multirow[b]{2}{*}{ Model } & \multicolumn{2}{|c|}{ Unstandardized Coefficients } & \multirow{2}{*}{\begin{tabular}{|l|} 
Standardized Coefficients \\
Beta
\end{tabular}} & \multirow[b]{2}{*}{$\mathrm{t}$} & \multirow{2}{*}{$\begin{array}{c}\text { p-value } \\
\text { Sig. }\end{array}$} \\
\hline & B & Std. Error & & & \\
\hline (Constant) & 266.521 & 177.180 & & 1.504 & .171 \\
\hline Gross Domestic Product (GDP) & .123 & .020 & 1.065 & 6.045 & .000 \\
\hline Per Capita GDP & -.006 & .004 & -.284 & -1.339 & .217 \\
\hline Total Early-Entrepreneurship Activity (TEA) & -7.660 & 9.294 & -.141 & -.824 & 434 \\
\hline a. Dependent Variable: Number of incubators & & & & & \\
\hline
\end{tabular}

T-critical value: 1.729

\section{Source: Research Findings (2016)}

From the table above, it is evident that at $95 \%$ confidence level, only Gross Domestic Product (GDP) $(\mathrm{t}=6.045, \mathrm{p}=$ $0.000)$, produced positive and statistically significant values (a high t-value, $\mathrm{p}<0.05)$. Per Capita GDP $(\mathrm{t}=-1.339, \mathrm{p}=$ $0.006)$ and Total Early-Entrepreneurship Activity (TEA) $(\mathrm{t}=$ $-.824, \mathrm{p}=0.434$ ), produced a negative and insignificant (low t-value, $p>0.05$ ) effect on the number of incubators in a country.

The constant value (266.521) shows that if Gross Domestic Product (GDP), Per Capita GDP and Total EarlyEntrepreneurship Activity (TEA) were rated zero, the number of incubators in country would be 266.521 . In order 


\section{International Journal of Science and Research (IJSR) \\ ISSN (Online): 2319-7064 \\ Index Copernicus Value (2013): 6.14 | Impact Factor (2015): 6.391}

to come up with the regression equation, stochastic error term estimate was assumed to be zero.

The equation was expressed as:

$\mathbf{Y}=\boldsymbol{\beta}_{0}+\boldsymbol{\beta}_{1} \mathbf{X}_{1}+\boldsymbol{\beta}_{2} \mathbf{X}_{2}+\boldsymbol{\beta}_{3} \mathbf{X}_{3}+\varepsilon$

$Y=266.521+0.123 X_{1}-0.006 X_{2}-7.660 X_{3}$

Where:

$\mathrm{Y}$ - Number of Incubators(Dependent variable)

$\mathrm{X}_{1}-\mathrm{X}_{3}-$ The independent variables

$\mathrm{X}_{1}$ - Gross Domestic Product (GDP)

$\mathrm{X}_{2}$ - Per Capita GDP

$\mathrm{X}_{3}$ - Total Early-Entrepreneurship Activity (TEA)

$\beta_{0}$ - Is the constant of the model

$\beta_{1}-\beta_{3}-$ Are the regression coefficients

$\varepsilon-$ Stochastic error term estimate

\subsection{Analysis of Variance}

Analysis of Variance (ANOVA) was done to verify the goodness of fit of the regression model. The study findings revealed that the regression model had a significance level of $0.1 \%$. This indicates that the model is ideal for making predictions on the future impact of economic growth on the number of business Incubators and vice versa. Business incubators have a significant impact on development of entrepreneurship.This is because the significant value (pvalue) is less than $5 \%$ and the $\mathrm{F}$ value (3.143) is greater than the F-Critical Value (2.740).

Table 1.7: Analysis of Variance (ANOVA)

\begin{tabular}{|c|c|c|c|c|c|c|}
\hline \multicolumn{7}{|c|}{ ANOVA $^{\mathbf{b}}$} \\
\hline \multicolumn{2}{|c|}{ Model } & Sum of Squares & df & Mean Square & F & Sig. \\
\hline \multirow{2}{*}{1} & Regression & 1405225.440 & 3 & 468408.480 & 16.311 & $.001^{\mathrm{a}}$ \\
\cline { 2 - 8 } & Residual & 229741.560 & 8 & 28717.695 & & \\
\cline { 2 - 8 } & Total & 1634967.000 & 11 & & & \\
\hline
\end{tabular}

a. Predictors: (Constant), Total early-entrepreneurship activity, Gross Domestic Product, Per Capita (GDP)

b. Dependent Variable: Number of incubators

Source: Research Findings (2016)

F-Critical Value $=2.740$

\section{Conclusions and Recommendation of Findings}

The findings of this study have shown that there is a strong relationship between economic development (Measured by GDP) and the number of Incubators found in a country. This study corroborates the earlier studies that ties entrepreneurship to economic development measured in terms of employment creation, income distribution and poverty reduction. This study shows that investment in Business incubators has the potential of paying economic dividends to a country. Business incubators need to be adopt as a policy instrument for entrepreneurship development.

\section{Areas of Further research}

There is need for longitudinal studies on Business incubator graduated tenants to establish effect on continued survival over a time period. There is need to compare business incubators best practices in different regions and their impact on entrepreneurship development. This will establish if environment has any role in success of business incubators.

\section{References}

[1] Aerts, K., Matthyssens, P. and Vandenbempt, K. (2007). Critical Role and screening practices of European business incubators. Technovation, Vol 27 (5) pp 254-267

[2] Al- Mubaraki, H. and Busler, M. (2012). A Comparative study of Incubation Landscapes in Europe and Middle East. European Journal of Business and Management, Vol 4 (10)

[3] Amezcua, S. Alejandro. (2011) Business Incubator as an Entrepreneurship policy. PHD Thesis- Published.

[4] Andrew, Atherton. \& Hannon, P. D. (2006). Localized strategies for supporting Incubation. Journal of Small Business and Enterprise Development, Vol 13 (1) pp. 48-61

[5] Ayyagari, M., Beck, T. and Dermirguc-Kunt, A. (2007). Small and Medium Enterprises across the Globe. Small Business Economics, Vol 29, 415-534

[6] Bearse, Peter. (1998). Impact Assessment of Business Incubators. Development Strategies Quarterly, Vol. 12 (4), 322-333

[7] Berry, O. (2009). Promoting High Growth Entrepreneurship in Israel, Giving machines a prime sense. Chairperson Venture partners: Gemini Israel Funds.

[8] BIAK (2012). Business Incubators Association of Kenya.

[9] Bowen, M., Morara, M., and Mureithi, S. (2009). Management of Business Challenges among Small Enterprises in Nairobi. KCA Journal of Business Management, Vol 2 (1).

[10] Caleb, M. Adelowo., Illori, M. Olugbenga. \& Orolabi, Siyanbola, Oluwala, A. B. (2015) Technological learning mechanism in Nigeria Technology Incubator Centre. African Journal of Economic and Management Studies, Vol. 6 (1), 72-89

[11] GEM (2012). Global Entrepreneurship Monitor Global Report

[12] GEM (2013). Global Entrepreneurship Monitor Global Report

[13] GEM (2014). Global Entrepreneurship Monitor Global Report

[14] GEM (2015). Global Entrepreneurship Monitor Global Report

[15] Hackett, S. M., \& Dilts. D. M. (2004) A Systematic Review of Business Incubators Research. Journal of Technology Transfer, Vol 29 (1), 55-82

[16] Hannon, Paul. (2004). A Qualitative sense Making Classification of Business Incubators: International Research Journal, Vol 7 (4), 274-283

[17] Jorge, Miguel. ,Carrillo, Rivera. (2007). an ex post Comparative analysis of SME formation in Brazil and Mexico, International Journal of Emerging Markets, Vol 2 (2) pp. 144-165

[18] Kfw Bankengruppe (2013c) Kfw Grundungsmonitor 2013 Frankfurt a M

[19] Klapper, L. and Richmond, C. (2009). Patterns of business creation, survival and growth: Evidence from a developing country. 


\section{International Journal of Science and Research (IJSR) \\ ISSN (Online): 2319-7064 \\ Index Copernicus Value (2013): 6.14 | Impact Factor (2015): 6.391}

[20] Lalkaka, R. (2002). Technology Business Incubators to help build an Innovation-Based Economy. Journal of Change Management, Vol 3 (2), 167-176

[21] Lilai, Xu. (2009). Business Incubators in China. Management Research Review, Vol 35 (1), 90-99

[22] Lindile, L. Ndabeni. (2008). The contribution of Business and Technology stations to Entreprise Development in South Africa, Development Sothern Africa, Vol 25 (3), 259-268

[23] Longnecker, J. G., Pelly, C. W., Moore, J. W. and Parich, L. E. (2006). Small Business Management and Entrepreneurial Emphasis. London: Thomson South Western.

[24] Masutha, M. and Rogers, C. M. (2014). Small entreprise development in South Africa: role of Business Incubators. Bulletin of Geography, social economic series No. 26, Turin: Nicholas Copernicus University. Pp 141-155.

[25] Meru, A. K. \& Struwig, M. (2011). An Evaluation of Entrepreneurs perception of Business Incubation Services in Kenya. International Journal of Business Administration, Vol 2 (4), 112-121.

[26] Natasha, Ramkissoon- Babwah, Jameela McDavid (2014). Selecting the right for a business Incubator; Lessons learnt from National Integrated Business Incubation System (IBIS) Programme of Trinidad and Tobago. Journal of Small Business and Entrepreneurship Development, Vol 2 (3) \& (4), 13-26

[27] Obaji, N.O., Olugu, M.U., \& Obiekwe, B.C. (2015). Business Incubators adaptation and success factors in Nigeria Context of a Developing Country. A Literature Review. International Journal of Science, Technology and Management, Vol 4 (1), 435-442

[28] OECD (1997). Technology Incubation: Nurturing Small Firms, Paris Conference.

[29] OECD (2005). SME's Thrive in Incubators and development Parks, Paris.

[30] OECD (2010). Organization of Economic Cooperation and Development Reports.

[31] Pam, Voisey. , Lynne, Gornall., Paul, Jones. \& Brychan, Thomas. (2006). the measurement of Success in a Business Incubator project. Journal of Small and Entreprise Development. Vol 13 (3), 454-468

[32] Paragivtis, Liargovas (2013). Business Incubators and Regional Development. European Union

[33] Rosa Caiazza (2014). Benchmarking of Business Incubators and Benchmarking. An international Journal, Vol 21(6), 1062-1069

[34] Safraz, A. Mian. (1996). Assessment Value- added Contributions of University Technology Incubators to Tenant Firm. Research Policy Vol 25, 325-335

[35] Seoane, F.J.F., Rodriguez, G. R. \& Rojo, D. A. (2014). The Influence of Training and gender in entrepreneurship through Business Incubators in Galicia (Spain). International Journal of Social Science and Entrepreneurship, 1 (9), 611-623

[36] Sternberg, R et al (2013): Global Entrepreneurship Monitor (GEM), Landebericht, Germany (2012) Hannover.

[37] Waeltring, Frank. \& Dornberger, Utz. (2014). Insights Study on the German Early stage Investing, Incubation and Business Angel System. GIZ
[38] World Bank (2016). World Bank economic reports, World Bank.

Notes

In absence of recentTEA data on Kenya, The study adopted Uganda's TEA data available in Literature to represent East Africa.

The study used historical data available from various studies to build a case. Although data used had varied dates due to studies done in different countries at different timelines, in the opinion of the author the focus was on the trend.

\section{Author Profile}

Ogutu Vincent Oduor received his BSc degree from the University of Nairobi, MSc in entrepreneurship at Jomo Kenyatta University of Agriculture and technology and is currently pursuing doctoral studies in Entrepreneurship at Jomo Kenyatta University of Agriculture and Technology.

Dr. Kihonge, Ephantus is a Senior Lecturer and Chairman of department at the Jomo Kenyatta University of Agriculture and Technology at the department of Human Resource Development, Westlands Campus. He did his Doctoral studies in the Universitie Plaise Bascal II, Clermont Ferrand, France. 